\title{
Economic Impact of Selected Conflicts in the Middle East: What Can We Learn from the Past?
}




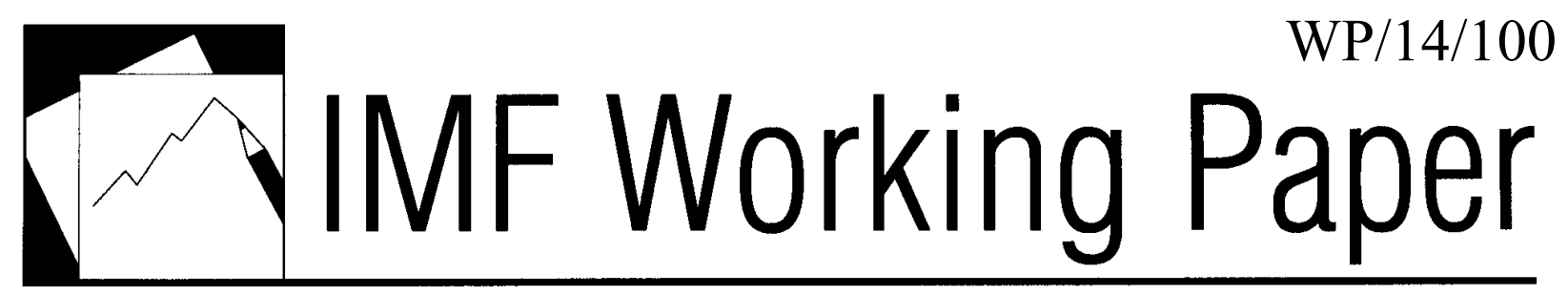

Economic Impact of Selected Conflicts in the Middle East: What Can We Learn from the Past?

Randa Sab

INTERNATIONAL MONETARY FUND 


\title{
IMF Working Paper
}

Middle East and Central Asia Department

Economic Impact of Selected Conflicts in the Middle East: What Can We Learn from the Past?

Prepared by Randa Sab*

Authorized for distribution by May Khamis

June 2014

\section{This Working Paper should not be reported as representing the views of the IMF.} The views expressed in this Working Paper are those of the author(s) and do not necessarily represent those of the IMF or IMF policy. Working Papers describe research in progress by the author(s) and are published to elicit comments and to further debate.

\begin{abstract}
Using narrative-based country-case studies, war episodes in the Middle East were examined to assess their economic impact on conflict and neighboring economies. The paper found that conflicts led to a contraction in growth, higher inflation, large fiscal and current account deficits, loss of reserves, and a weakened financial system. Post-conflict recovery depended on the economic and institutional development of the country, economic structure, duration of the war, international engagement, and prevailing security conditions. The net economic impact on neighboring countries varied according to their initial economic conditions, number and income level of refugees they hosted, economic integration, and external assistance.
\end{abstract}

JEL Classification Numbers: N15, N45

Keywords: Conflict, post-conflict economic recovery, Middle East

Author's E-Mail Address: rsab@imf.org

\footnotetext{
* The author is grateful to Adnan Mazarei, May Khamis, Annalisa Fedelino, Andrea Gamba, Peter Gruskin, Kristina Kostial, Alina Luca, Edouard Martin, Eric Mottu, Najla Nakhle, Francisco Parodi, Carlo Sdralevich, Younes Zouhar, for their useful comments; Kamal Krishna for research support; and Cecilia Pineda for administrative support.
} 
Introduction. .$\underline{3}$

A. Literature Review 7

B. Economic Impact of the Conflicts and Trends in Post-Conflict Recovery

C. Regional Spillovers $\underline{12}$

D. Conclusions: What Can We Learn from the Past? $\underline{15}$

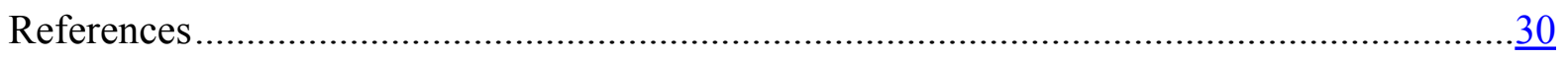

Tables

1. Macroeconomic Indicators for War Episodes for Lebanon, Kuwait, and Iraq .................. $\underline{5}$

2. Selected War Episodes in MENA: Years Required for Selected Macro Variables to Return to Their Pre-War Levels..............................................................................

Figure 1. Cumulative Real GDP Loss During the War ................................................. $\underline{8}$

Appendix: Impact of Wars on Selected Countries....................................................... 17

A. Lebanon Civil War (April 13, 1975-October 13, 1990) .........................................

B. Gulf War-Kuwait's Invasion by Iraq (August 2, 1990-February 28, 1991) ................

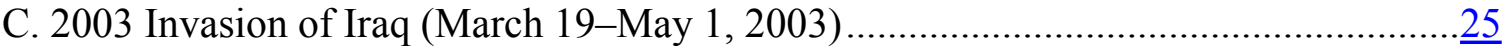

Appendix Figures

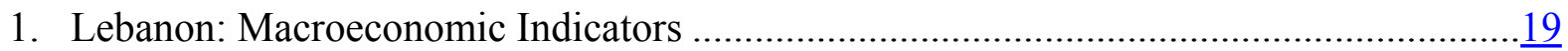

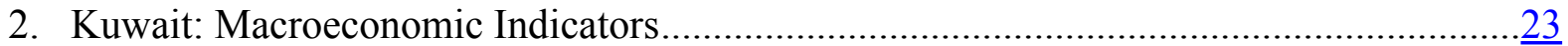

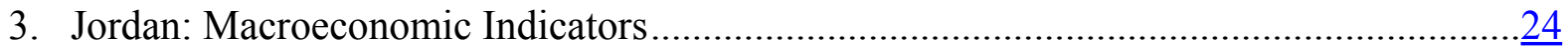

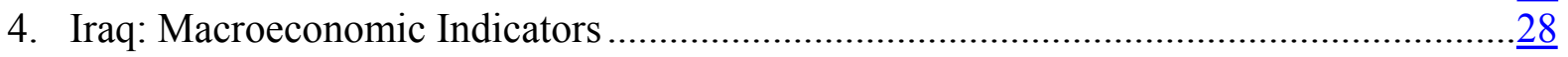

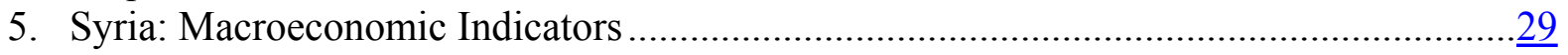




\section{INTRODUCTION}

In this paper, we examine the economic impact that selected war episodes in the Middle East had on conflict and in neighboring countries. This study could help draw lessons and assess the potential impact of ongoing political conflicts on the respective economies in the region and their neighbors. The selected war episodes include the Lebanese civil war (April 13, 1975-October 13, 1990), the Gulf War-Kuwait's Invasion by Iraq (August 2, 1990-February 28, 1991), and the 2003 invasion of Iraq (March 19-May 1, 2003). ${ }^{1}$ These countries were selected based on: (i) the representativeness of their economic structure within the region (i.e., by providing a sample of MENA oil and non-oil producers); (ii) the duration and intensity of the conflicts in which they were involved; (iii) similar cultural and historical background; and (iv) their regional as well as global importance. The neighboring countries examined from those war episodes include Jordan and Syria since their economies were the most affected by the large inflow of war refugees.

We combine a narrative-based country-case study methodology organized according to common themes with a quantitative analysis of macroeconomic variables. This approach allows for an explicit consideration of the historical context and specific country characteristics influencing key economic variables. Such context—which is particularly informative in the case of violent conflicts - might not have been adequately captured in the case of a purely empirical analysis of a broader cross-section of countries. ${ }^{2}$ The themes in the country-case studies presented in the appendix include: (i) a background section; (ii) the impact of the conflict on the economy; and (iii) the post-conflict recovery. The quantitative analysis includes a wide range of key macroeconomic variables in the real, fiscal, external and monetary sectors (Appendix Figures 1-5). The variables were drawn from different sources, including the World Economic Outlook, the Regional Economic Outlook, the World Bank's World Development Indicators, and International Monetary Fund (IMF) documents, including staff reports and IMF Occasional Papers. The results should be interpreted with caution due to the limited sample size and because data covering war episodes suffer from weaknesses, resulting from the looting or the destruction of institutions collecting data and the absence of government.

\footnotetext{
${ }^{1}$ While the 2003 invasion of Iraq lasted few weeks, Iraq was essentially in low-grade civil war throughout much of the last decade until the summer/fall of 2009.

${ }^{2}$ Furthermore, an econometric analysis of the cases at hand would have been precluded by limited data availability and comparability. For a well-known empirical analysis of economic causes of civil wars, see Collier and Hoeffler (1998).
} 
Table 1 shows comparisons across different wars. It shows key macroeconomic variables a year prior to the war, the initial war year, and seven years after the conclusion of the war to help understand the speed of recovery. The data indicated that conflicts generally led to a contraction in growth, higher inflation, large fiscal and current account deficits, a loss of foreign reserves as well as a weakened financial system. However, the magnitude of the changes in the macroeconomic variables varied significantly across countries.

Our findings indicate that post-conflict recovery depended on the economic and institutional development of the country, structure of the economy (oil versus non-oil), the duration of the war, and engagement of the international community. The speed of economic recovery differed significantly across countries. It took 20 years after the war for real GDP to recover to its pre-war level in Lebanon, seven years in Kuwait, and one year only in Iraq. On the other hand, real GDP per capita in Lebanon has not yet fully returned to its pre-war level, and the persistent difficult security and political conditions continue to weigh down on growth. In Kuwait, real GDP per capita was well above its pre-war level two years after the war ended due to the significant contraction in its population. In Iraq, real GDP per capita fully recovered to its pre-war level three years after the war. Despite relatively strong real GDP growth rates in Iraq, economic governance has weakened, resulting from an increasingly difficult political process and worsening security conditions. ${ }^{3}$ In general, exchange rate stability contributed to containing inflationary pressures during the recovery period in all three countries. The fiscal and external stance differed significantly across countries during the recovery period, with oil producing countries posting fiscal and external surpluses few years after the end of the war. The health of the financial system also had to be strengthened after being affected by these conflicts.

Lastly, our analysis indicated that the net economic impact of wars on neighboring countries varied according to their initial economic conditions, the number and economic characteristics (income level) of refugees, the degree of economic integration with the conflict country and with the rest of the world, and the extent of external assistance the country received.

The sections below review the literature and summarize shared and country-specific trends for each of the conflicts noted above, both in regard to the impact of the conflict on the affected economy and also the post-conflict recovery. They also summarize spillovers to countries in the region, where relevant.

\footnotetext{
${ }^{3}$ See Sdralevich and others (2013).
} 
Table 1. Macroeconomic Indicators for War Episodes for Lebanon, Kuwait, and Iraq

\begin{tabular}{|c|c|c|c|c|c|c|c|c|c|}
\hline & \multirow{2}{*}{$\begin{array}{l}\text { Pre-War } \\
\text { Year 1/ }\end{array}$} & \multirow{2}{*}{$\begin{array}{l}\text { Initial War } \\
\quad \text { Year 2/ }\end{array}$} & \multicolumn{7}{|c|}{ Post-War Years at Time 3/ } \\
\hline & & & $t+1$ & $t+2$ & $t+3$ & $t+4$ & $t+5$ & $t+6$ & $\mathrm{t}+7$ \\
\hline \multicolumn{10}{|c|}{ Real GDP index } \\
\hline Lebanon & 100.0 & 69.7 & 38.5 & 40.2 & 43.0 & 46.5 & 49.5 & 51.5 & 56.8 \\
\hline Kuwait & 100.0 & 73.8 & 65.6 & 87.7 & 95.3 & 96.6 & 97.2 & 99.6 & 103.2 \\
\hline Iraq & 100.0 & 64.2 & 102.6 & 107.1 & 118.0 & 119.6 & 127.5 & 134.9 & 142.8 \\
\hline \multicolumn{10}{|c|}{ Inflation (percentage change) } \\
\hline Lebanon & 12.3 & 20.0 & 50.1 & 99.8 & 24.7 & 8.2 & 10.3 & 8.9 & 7.7 \\
\hline Kuwait & 3.3 & 15.8 & -0.3 & 0.6 & 2.4 & 2.5 & 3.0 & 0.8 & 0.6 \\
\hline Iraq & 19.3 & 33.6 & 27.0 & 37.0 & 53.2 & -10.1 & 12.7 & 6.9 & 2.9 \\
\hline \multicolumn{10}{|c|}{ Exchange rate (percentage change, + depreciation) } \\
\hline Lebanon & -10.8 & -1.1 & 33.5 & 84.5 & 1.7 & -3.5 & -3.5 & -3.1 & -2.0 \\
\hline Kuwait & 0.0 & -2.7 & 1.4 & 2.7 & -1.2 & 0.3 & 0.3 & 1.3 & 0.5 \\
\hline Iraq & 1.5 & -3.0 & -23.5 & 1.1 & -0.1 & -14.5 & -4.9 & -1.9 & 0.0 \\
\hline \multicolumn{10}{|c|}{ Fiscal balance (in percent of GDP) } \\
\hline Lebanon & 5.0 & 2.0 & -16.0 & -11.4 & -7.8 & -17.2 & -18.0 & -21.4 & -27.3 \\
\hline Kuwait & $\ldots$ & -32.0 & -49.6 & -15.7 & -9.1 & -1.9 & 11.6 & 17.2 & 6.9 \\
\hline Iraq & $\ldots$ & $\ldots$ & -35.4 & 4.1 & 10.7 & 7.8 & -0.9 & -12.7 & -4.3 \\
\hline \multicolumn{10}{|c|}{ Revenue (in percent of GDP) } \\
\hline Lebanon & 20.0 & 15.0 & 13.0 & 12.0 & 15.6 & 17.9 & 17.2 & 17.6 & 16.7 \\
\hline Kuwait & $\ldots$ & 60.3 & 41.2 & 45.6 & 49.4 & 52.7 & 56.1 & 60.8 & 58.9 \\
\hline Iraq & $\ldots$ & $\ldots$ & 56.1 & 67.3 & 61.0 & 54.0 & 56.4 & 46.2 & 46.4 \\
\hline \multicolumn{10}{|c|}{ Expenditure (in percent of GDP) } \\
\hline Lebanon & 15.0 & 14.0 & 29.0 & 23.4 & 23.4 & 35.1 & 35.2 & 39.0 & 44.0 \\
\hline Kuwait & $\ldots$ & 92.3 & 90.8 & 61.4 & 58.5 & 54.6 & 44.5 & 43.7 & 52.0 \\
\hline Iraq & $\ldots$ & $\ldots$ & 91.5 & 63.2 & 50.3 & 46.1 & 57.3 & 58.9 & 50.7 \\
\hline \multicolumn{10}{|c|}{ Total public debt (in percent of GDP) } \\
\hline Lebanon & $\ldots$ & $\ldots$ & 66.2 & 51.0 & 49.8 & 70.6 & 78.5 & 99.8 & 98.9 \\
\hline Kuwait & $\ldots$ & $\ldots$ & 120.8 & 86.1 & 89.8 & 76.7 & 56.6 & 50.2 & 54.0 \\
\hline Iraq & $\ldots$ & $\ldots$ & 334.9 & 220.4 & 152.0 & 116.1 & 72.6 & 84.0 & 52.2 \\
\hline
\end{tabular}

Sources: IMF World Economic Outlook; Eken and others (1995); Eken and Helbling (1999); Regional Economic Outlook; World Bank's World Development Indicators; and IMF calculations.

1/ For Lebanon, the pre-war year is 1974; for Kuwait, 1989; and for Iraq, 2002.

2/ The initial war year for Lebanon is 1975; for Kuwait, 1990; and for Iraq, 2003.

3/ The post-war year for Lebanon starts in 1991; for Kuwait, 1992, and for Iraq, 2004.

CInternational Monetary Fund. Not for Redistribution 
Table 1. Macroeconomic Indicators for War Episodes for Lebanon, Kuwait, and Iraq (concluded)

\begin{tabular}{|c|c|c|c|c|c|c|c|c|c|}
\hline & \multirow{2}{*}{$\begin{array}{l}\text { Pre-War } \\
\text { Year 1/ }\end{array}$} & \multirow{2}{*}{$\begin{array}{l}\text { Initial War } \\
\quad \text { Year 2/ }\end{array}$} & \multicolumn{7}{|c|}{ Post-War Years at Time 3/ } \\
\hline & & & $\mathrm{t}+1$ & $t+2$ & $t+3$ & $t+4$ & $t+5$ & $t+6$ & $\mathrm{t}+7$ \\
\hline \multicolumn{10}{|c|}{ Current account balance (in percent of GDP) } \\
\hline Lebanon & 2.1 & -3.3 & -56.7 & -49.9 & -6.1 & -6.2 & -9.6 & -10.1 & -32.0 \\
\hline Kuwait & 40.3 & 20.3 & -2.3 & 10.4 & 13.0 & 18.4 & 22.6 & 25.9 & 8.5 \\
\hline Iraq & $\ldots$ & $\ldots$ & -29.3 & 3.9 & 12.9 & 7.7 & 12.8 & -8.3 & 3.0 \\
\hline \multicolumn{10}{|c|}{ Exports of goods and services (in percent of GDP) } \\
\hline Lebanon & 43.1 & 40.5 & 11.2 & 10.8 & 51.6 & 47.0 & 43.5 & 41.1 & 36.7 \\
\hline Kuwait & 53.3 & 45.1 & 40.5 & 48.0 & 51.1 & 52.3 & 52.3 & 52.9 & 43.9 \\
\hline Iraq & $\ldots$ & $\ldots$ & 47.0 & 46.9 & 46.4 & 43.6 & 48.3 & 36.4 & 40.0 \\
\hline \multicolumn{10}{|c|}{ Imports of goods and services (in percent of GDP) } \\
\hline Lebanon & 62.8 & 66.4 & 85.4 & 75.7 & 69.9 & 65.6 & 65.6 & 58.8 & 71.4 \\
\hline Kuwait & 40.6 & 31.6 & 52.0 & 48.1 & 44.8 & 46.5 & 41.4 & 42.4 & 51.1 \\
\hline Iraq & $\ldots$ & $\ldots$ & 66.3 & 49.7 & 35.8 & 33.4 & 36.8 & 48.0 & 39.3 \\
\hline \multicolumn{10}{|c|}{ Gross international reserves (in billions of \$) } \\
\hline Lebanon & 1.7 & 1.6 & 1.2 & 1.4 & 2.2 & 3.8 & 4.5 & 6.0 & 5.9 \\
\hline Kuwait & $\ldots$ & $\ldots$ & $\ldots$ & 4.3 & 3.6 & 3.7 & 3.8 & 3.7 & 4.1 \\
\hline Iraq & $\ldots$ & $\ldots$ & 7.9 & 12.0 & 20.0 & 31.5 & 50.2 & 44.3 & 50.6 \\
\hline \multicolumn{10}{|c|}{ Broad money (in percent of GDP) } \\
\hline Lebanon & 105.9 & 140.8 & 121.8 & 125.0 & 119.5 & 128.4 & 126.9 & 143.2 & 165.7 \\
\hline Kuwait & 74.1 & 115.2 & 113.4 & 93.3 & 100.9 & 90.9 & 77.7 & 82.7 & 95.6 \\
\hline Iraq & $\ldots$ & $\ldots$ & $\ldots$ & 20.1 & 20.8 & 24.4 & 23.5 & 35.8 & 33.8 \\
\hline
\end{tabular}

Sources: IMF World Economic Outlook; Eken and others (1995); Eken and Helbling (1999); Regional Economic Outlook; World Bank's World Development Indicators; and IMF calculations.

1/ For Lebanon, the pre-war year is 1974; for Kuwait, 1989; and for Iraq, 2002.

2/ The initial war year for Lebanon is 1975; for Kuwait, 1990; and for Iraq, 2003.

3/ The post-war year for Lebanon starts in 1991; for Kuwait, 1992, and for Iraq, 2004. 


\section{A. Literature Review}

Several studies have examined the economic impact of conflicts. Collier (1999) found that civil wars result in a decline in real GDP per capita since wars lead to a direct output reduction and a gradual loss of capital stock and dissaving. These affect economic sectors differently with capital and transaction-intensive sectors, such as manufacturing, construction, transportation, distribution, as well as finance, contracting more rapidly than total GDP. On the other hand, subsistence agriculture increases more than GDP.

Gupta and others (2002) examined the fiscal consequences of armed conflict and terrorism in a group of low- and middle-income countries. The results showed that in the 22 conflict episodes examined armed conflict resulted in lower economic growth, higher inflation, lower tax revenues and investment. They also found that conflicts had an adverse impact on growth reflecting a shift of resources toward military spending at the expense of spending on more productive economic sectors.

Addison and others (2002) assessed the impact of conflicts on the financial sector in 79 countries. They found that financial development is vulnerable to conflict. In particular, their results showed that conflict reduces the demand for domestic currency, results in weak financial regulation, has a negative impact on financial development, which is further exacerbated by more intensive conflicts.

Other studies have examined spillover effects of conflict in neighboring countries. Ades and others (1997) found that political instability in neighboring countries had an adverse effect on a country's economic growth. The study found two main channels through which regional instability lowers growth: (i) through a disruption of trade, and (ii) increased military spending. Similarly, De Groot (2010) found that directly bordering countries in Africa have a negative spillover from conflict countries, while non-bordering neighboring countries could have a positive spillover. Directly bordering countries may have a negative impact on growth in part due to the poor or unskilled refugees they host, in addition to the disruption in trade. On the other hand, refugees who are able to move to a non-bordering neighboring country tend to be wealthier and more skilled, therefore leading to a positive spillover.

\section{B. Economic Impact of the Conflicts and Trends in Post-Conflict Recovery}

\section{Economic impact}

The conflicts in Lebanon, Kuwait, and Iraq impacted the countries' respective economies through multiple channels (Organigram 1). The conflicts led to a contraction in aggregate supply through the disorganization of production, destruction of physical capital, and dislocation of labor. From a growth accounting perspective, this meant both a reduction in 
total factor productivity-because economic efficiency was compromised and technology absorption was interrupted - and a dwindling of physical as well as human capital. ${ }^{4}$ This was manifested in a contraction of output, acceleration of inflation, large fiscal and current account deficits, a loss of reserves, as well as weaker financial systems.

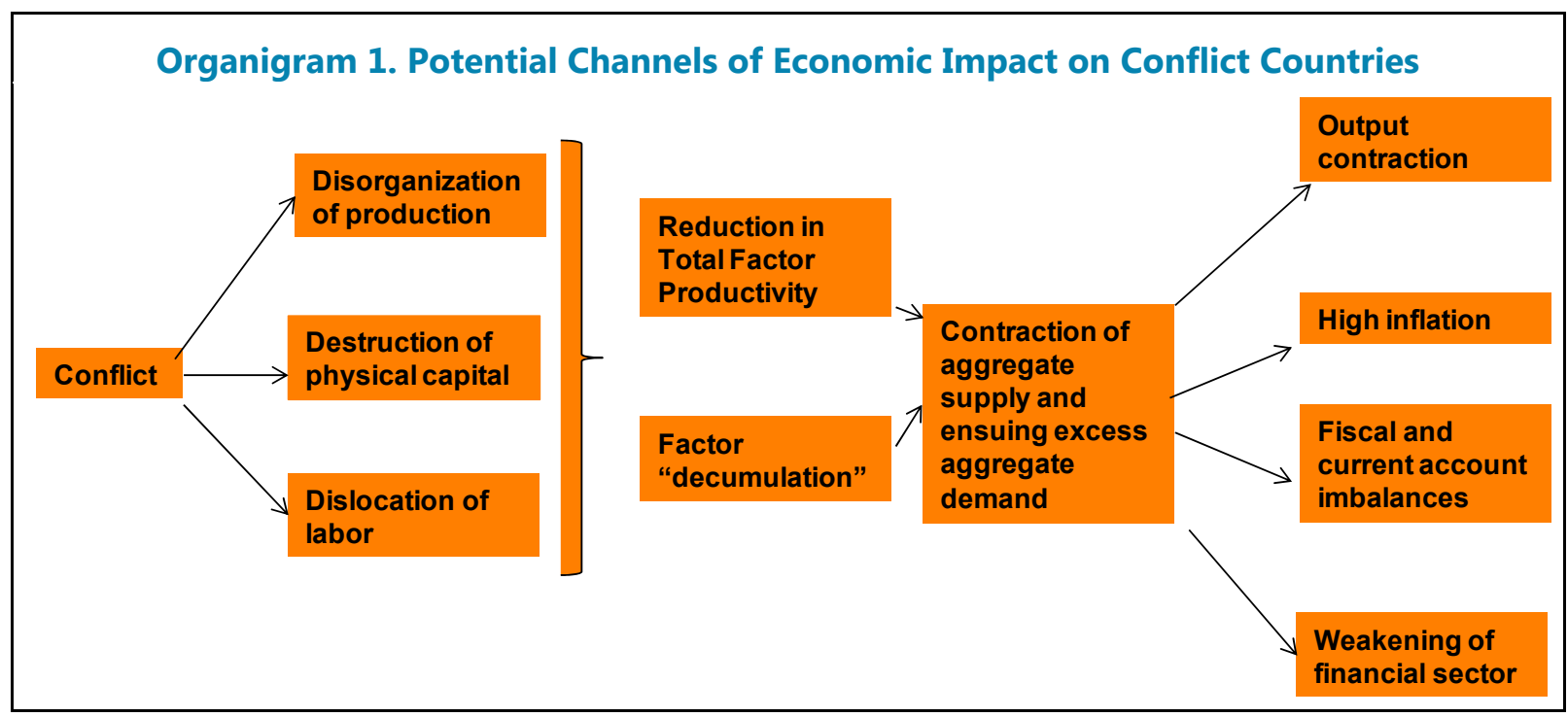

Growth: The contraction in real GDP varied significantly across countries. Lebanon's real GDP declined sharply, by more than 70 percent during the civil war (Figure 1). Given the long duration of the war in Lebanon, real GDP fluctuated significantly according to the intensity of the conflict, with some years showing positive growth. ${ }^{5}$ Kuwait and Iraq, the two oil producers, saw also large declines in output with significant damage to their oil sectors and a fall in oil production. Kuwait saw a decline of about 55 percent in its real GDP in 1991 from its pre-war

Figure 1. Cumulative Real GDP Loss During the War (In percent)

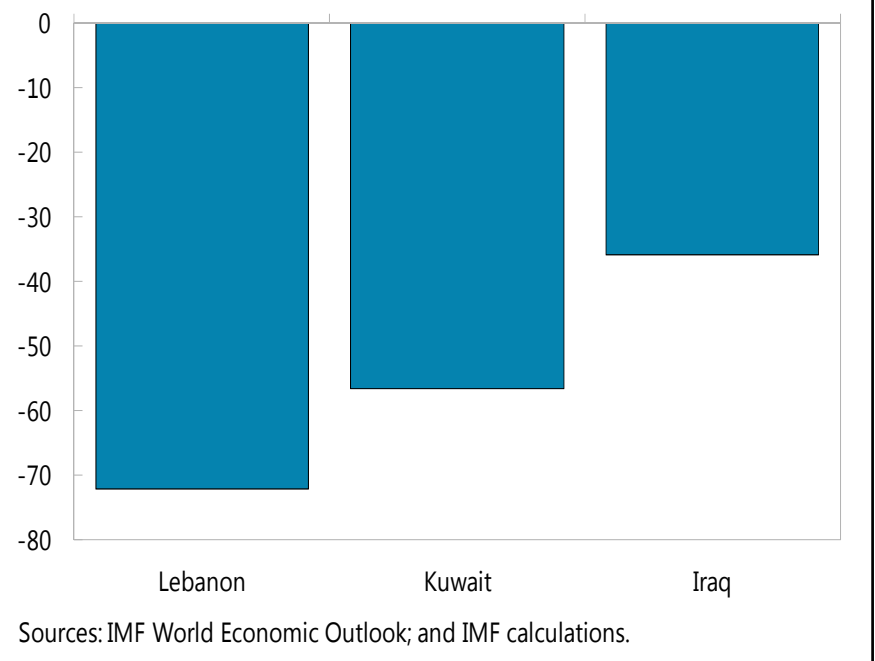
level of 1989, while Iraq's real GDP contracted by about 35 percent in 2003.

${ }^{4}$ For more on growth accounting, see Caselli (2008).

${ }^{5}$ Collier and others (2004) found that civil wars lasted on average seven years. They also found that low per capita GDP, high inequality, and ethnic divisions could lengthen conflicts. On the other hand, according to Bennett and Stam (1996) international wars lasted for about 11 months. 
Inflation and exchange rate: Inflation picked up with varying degrees across countries. Lebanon and Iraq already had high inflation rates in their pre-war year, and inflation rates jumped further during the war. In Lebanon, the consequent rapid growth in liquidity (associated with the banking sector's financing of the deficits) compared with economic activity, and the erosion of private sector confidence, led to continuous pressures on the Lebanese pound, which was floating since 1952, heightened inflationary pressures, and resulted in high levels of currency substitution. Only Lebanon experienced a striking depreciation of the exchange rate and a sizable acceleration in inflation, both reaching about 485 percent (y-o-y) in 1987. At the same time, deposit dollarization increased to about 90 percent in 1987 from 23 percent in 1974, prior to the war. In Iraq, as a result of supply disruptions caused by the war, inflation increased to 34 percent during 2003 from 19 percent in 2002. Although inflation in Kuwait also increased, it was lower than in the other countries reviewed here probably due to its peg to a currency basket and its tradition of low inflation. Kuwait and Iraq, on the other hand, did not experience a significant movement in their exchange rates during the war. Kuwait had large foreign reserves to support its currency and Iraq faced significant liquidity shortage during the war. ${ }^{6}$ Kuwait did not experience a significant change in deposit dollarization ratios likely as a result of the relatively lower variability in inflation. There are no data on dollarization for Iraq prior or during the war.

Fiscal sector: The war led to a worsening in the fiscal stance in all three countries. The absence of a central government authority compromised revenue collection capacity, leading to a deterioration in Lebanon's fiscal stance and its ability to provide public services. In Kuwait, war-related factors contributed to revenue shortfalls, rising public spending, and high deficit levels during 1990/91-1991/92, aggravated by significant foreign reserves draw-downs. In particular, the war led to a collapse in oil exports and other revenue sources during 1990/91. After liberation, the authorities waived import duties and most fees and charges. A large part of the expenditure increase during this period was due to transfers abroad - for payments related to Desert Shield/Desert Storm and to Kuwaiti citizens temporarily living abroad. In Iraq, the 2003 conflict made it difficult to evaluate fiscal policy for the year as a whole. There are no data available on public debt for the war years in any of the countries analyzed, although Iraq already suffered from a crippling debt burden.

External sector: Current account balances deteriorated in the countries under review as a result of the conflicts. The current account in Lebanon posted deficits during most of the war years. Capital flight and a substantial emigration of workers contributed to the deterioration in Lebanon's external accounts, further aggravated by a reduced access to foreign financing. As a result, gross reserves declined. Kuwait also ran a significantly large current account deficit in 1991 (see explanation above). There are no data on the current

\footnotetext{
${ }^{6}$ According to the Economist Intelligence Unit (EIU, 2003), the official value of the Iraqi dinar remained fixed since 1982, but there was a black market rate which showed no relation to its black-market rate.
} 
account in Iraq but at the beginning of the 2003 conflict, close to $\$ 1$ billion in foreign currency was taken out of the Central Bank of Iraq's (CBI) vaults, but most of this was subsequently recovered and used to finance government operations. Gross international reserves of the CBI were reported to be about $\$ 1.1$ billion by end-2003 (about 1.2 months of imports of goods and services).

Financial sector: The conflicts generally led to significant disruptions in the financial sectors of the affected countries. For instance, Lebanon's banking system was significantly weakened during the conflict, greatly diminishing its prior role as a regional financial intermediary. In Kuwait, the banking system already weak prior to the invasion due to the stock market crash in 1982 — which left banks with a large volume of nonperforming loans was further aggravated by the war. Some key financial sector developments in Kuwait during this period included: (i) severe disruption of financial contracts; (ii) destruction of assets serving as collateral; (iii) looting of banking system assets; (iv) looting of gold holdings and unissued currency of the Central Bank of Kuwait; (v) collapse in the value of real estate and financial assets; and (vi) some disruption to financial records, mitigated by the transfer of information abroad. In Iraq, the financial sector was dominated by two large state-owned banks, which suffered liquidity and solvency problems because most of their assets were in treasury bills or in loans to state-owned enterprises.

\section{Post-conflict recovery}

The findings showed that post-conflict recovery depended on the structure of the economy. For a non-oil producing country such as Lebanon, aggregate supply tended to take longer to catch up with growing aggregate demand. Large fiscal and current account deficits in post-war years reflected this continuing excess demand. For oil-rich economies such as Iraq and Kuwait, where oil production represented a significant part of aggregate supply, output recovery happened faster as oilfields were reactivated relatively quickly. Furthermore, the fact that most oil production was exported allowed post-conflict countries, such as Iraq and Kuwait to obtain current account surpluses in a relatively short period and recover their international reserves.

Growth: The speed of economic recovery differed significantly across countries (Table 2). Real GDP in Lebanon recovered gradually, reaching its pre-war level only in 2010, while real GDP per capita still remains well below its pre-war level (Appendix). Lebanon suffered important

Table 2. Selected War Episodes in MENA: Years Required for Selected Macro Variables to Return to Their Pre-War Levels

\begin{tabular}{|lrr|}
\hline & Real GDP & Real GDP per Capita \\
\hline Lebanon & 20 & Still below pre-war level \\
Kuwait & 7 & 2 \\
Iraq & 1 & 3 \\
\hline Sources: IMF World Economic Outlook; and IMF calculations. \\
\hline
\end{tabular}


political and security setbacks since the end of the war, adversely affecting its growth. ${ }^{7}$ In Kuwait, real GDP recovered fully, seven years after the end of the war. Its real GDP per capita was well above its pre-war levels two years after the war. This is due to the significant contraction in Kuwait's population of about 30 percent compared to its pre-war level. ${ }^{8}$ In Iraq, real GDP recovered fully, one year after the war, while its real GDP per capita recovered three years after the end of the war to its pre-war level. ${ }^{9}$ Poor governance and judiciary system, weak regulations, and insufficient security have kept Iraq at the bottom of global rankings for doing business. Foreign direct investment in Iraq, particularly in the nonoil sector, is lower than in other oil-exporters in MENA. ${ }^{10}$

Inflation and exchange rate: In general, exchange rate stability contributed to containing inflationary pressures during the recovery period. For example, in Lebanon, to stabilize expectations and achieve rapid disinflation, an exchange-rate-based nominal anchor policyadopted at the end of 1992 - was implemented by means of a supportive interest rate policy. In Kuwait, the price increases that had occurred during the occupation were reversed by late 1991 following the opening of the economy to imports, and inflation after 1992 was small. In Iraq, the CBI followed a policy of exchange rate stabilization, which has translated in a de facto peg of the exchange rate since early 2004, thereby helping contain inflation. However, inflation remained high during 2004-06 partly due to the insurgency, and the resulting acute shortages of certain goods.

Fiscal sector: The fiscal stance differed significantly across countries during the recovery period, with oil producing countries posting fiscal surpluses few years after the end of the war. In Lebanon, the acceleration in the growth of capital spending, together with large and increased current spending and the slow pick up in revenues, led to sizable fiscal imbalances. While the deficit fell from 16 percent of GDP in 1991 to about 8 percent in 1993, it rose and remained high thereafter. Deficit financing took mostly the form of issuance of government papers denominated in local currency, which were primarily held by domestic banks.

Consequently, the public debt increased rapidly. Kuwait had large fiscal deficits after the war

\footnotetext{
${ }^{7}$ Salti (2012) notes that persistent political instability in Lebanon continued to create a significant output cost for the country several years after the war ended.

${ }^{8}$ In 1992 and 1993, the non-oil sector growth was weak in Kuwait. This reflected mainly three factors: (i) a population policy aimed to reach a balance between Kuwaitis and expatriates led to a decline in the population, which constrained domestic demand, capacity utilization, and the availability of skilled labor; (ii) few opportunities for private sector investment; and (iii) uncertainties about the resolution of problem loans held by banks.

${ }^{9}$ In both 2005 and 2006 in Iraq, the source of growth was from non-oil economic activity. The lack of progress in increasing oil output reflected a combination of low investment (with project implementation impeded, by violence), and technical problems with the existing infrastructure at that time.

${ }^{10}$ Sdralevich and others (2013).
} 
and it started to post a fiscal surplus in 1996, five years after the end of the war. Kuwait's debt settlement program, approved in May 1992, entailed the buy-out with government bonds of "problem" loans extended by domestic banks and investment companies to Kuwaiti nationals. Covered by the buy-out were nonperforming credits (outstanding as of August 1990) related to both the war and the 1982 stock market crash. Therefore, the government virtually took the burden of bad debts held by Kuwaiti nationals, thus transforming private into public sector debt. Iraq posted fiscal surpluses for few years after the end of the war but the decline in oil prices during end-2008-2010 led to negative fiscal balances during those years. However, Iraq has successfully restructured its debt bringing it to more sustainable levels.

External sector: Similarly, oil producing economies recorded current account surpluses few years after the end of the wars. High interest rates in Lebanon attracted large capital inflows. These inflows, combined with remittances, foreign investment into the real estate sector, and financing for the reconstruction program, were more than enough to finance the country's large current account deficits. Foreign exchange reserves also sharply rose as a result. In Kuwait, the current account resumed its traditional surplus position in 1993. In Iraq, the current account balance has been in surplus most of the years since 2005 driven by oil exports.

Financial sector: The health of the financial system needed to be strengthened after the war. Particularly during 1990-93 and 1997-98, several Lebanese banks - especially those mostly affected by the conflict - had to close or merge with others. Banking system consolidation was stimulated by a 1993 law that expired in 1998. The main mechanism for consolidation took the form of limited concessional loans from the central bank covering the goodwill value of the acquisition cost. In Kuwait, with the debt settlement process, commercial banks were able to achieve strong capital adequacy positions, in view of the considerable weight that government bonds had in their portfolios. Iraq's financial system was already underdeveloped at the onset of the conflict and dominated by two large state-owned banks, the restructuring of which has not been completed so far.

\section{Regional Spillovers}

Although it is difficult to disentangle the impact of the war from other exogenous factors affecting neighboring economies, spillover analysis from conflicts allows for a better understanding of trends in key macroeconomic variables (Organigram 2). This could help draw lessons from the economic impact of ongoing conflicts in neighboring countries. Overall, our analysis indicated that the net impact varied according to initial economic conditions in neighboring countries, the number and income level of refugees, economic integration, and the extent of external assistance. In the case of Jordan, the spillover was largely positive: despite the initial negative impact that the Gulf War and the 2003 invasion of Iraq had on its economy, the country ended up benefiting from both the higher demand 
from refugees (1990 Gulf War) as well as external assistance (2003 invasion of Iraq). Syria, however, was adversely affected by the war in Iraq due to the negative impact on its exports and investment, and as the number of Iraqi refugees it hosted was much higher than in Jordan. ${ }^{11}$ Also, Syria did not receive foreign grants — despite the serious refugee situationdue to its relative international isolation back then. In the case of the Lebanese civil war, the economic impact on neighboring countries was limited as the Lebanese migrated to the Gulf and Western countries.

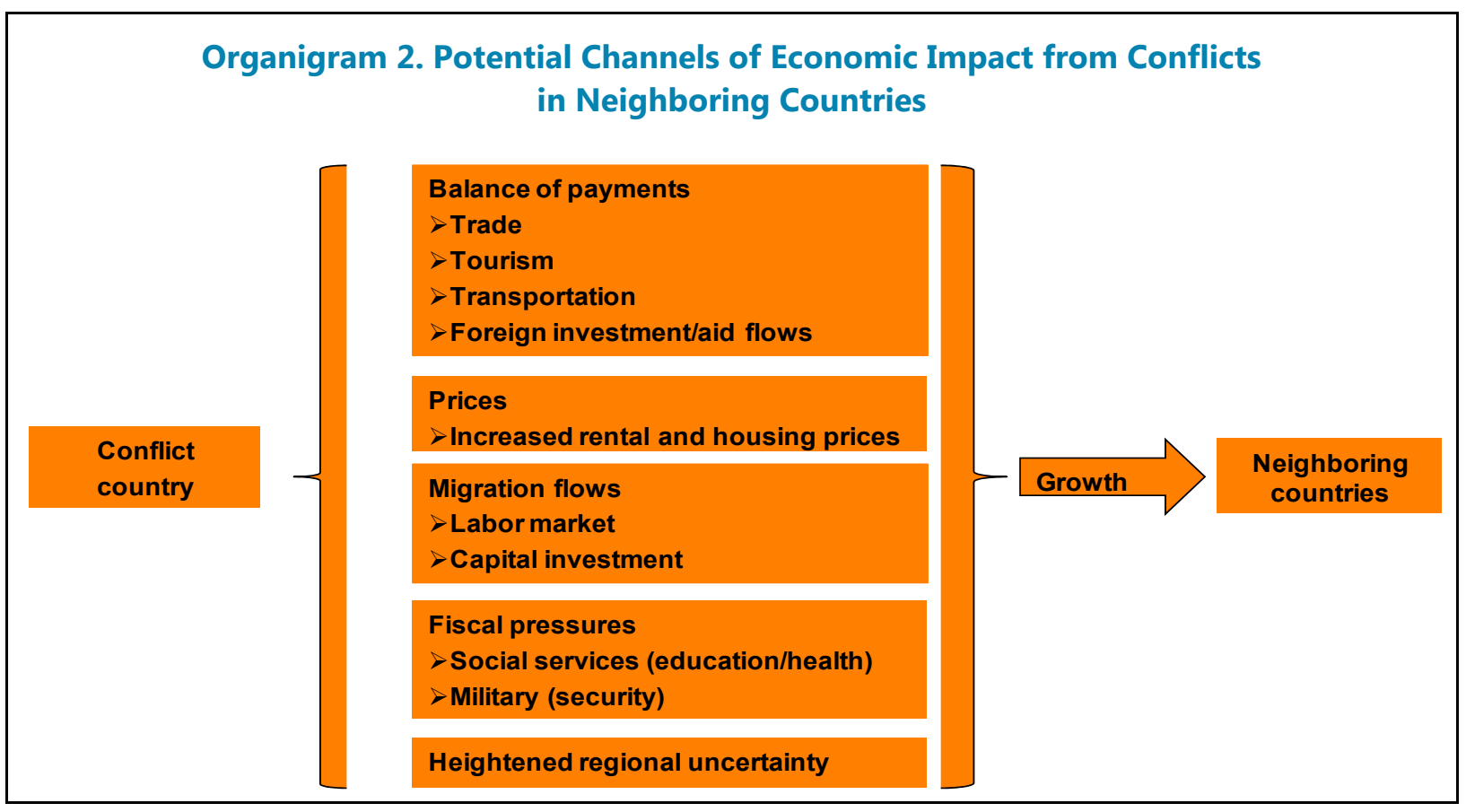

In addition, neighboring countries' macroeconomic variables were affected even prior to the conflicts reflecting the political uncertainty in the region with respect to an impending conflict. For instance, in Jordan, despite its strong growth in 2002, domestic demand remained subdued resulting from the wait-and-see stance of the private sector due to the intensified conflict in West Bank and Gaza and uncertainties resulting from the impending war in Iraq. ${ }^{12}$ Similarly, in mid-2002 in Syria, prior to the war in Iraq, the free market exchange rate came under pressure mainly reflecting political uncertainties in the region.

\footnotetext{
${ }^{11}$ According to government estimates, the figure of refugees from Iraq stood at 450,000 in Jordan, 50,000 in Lebanon and 1.1 million in Syria. But the number of refugees registered with United Nations High Commissioner for Refugees (UNHCR) was considerably smaller: around 52,000 in Jordan, 10,000 in Lebanon, and 206,000 in Syria at the end of March 2009. Because the Iraq-Syria border remained largely open, and because there was considerable movement across that border, it is difficult to determine exactly how many Iraqis resided in Syria. Moreover, many of the Iraqi refugees were well educated, had good jobs, and lived a reasonably comfortable lifestyle (UNHCR, 2009).

${ }^{12} \operatorname{IMF}(2003 a)$.
} 


\section{Jordan in the aftermath of the 1990 Gulf War}

- Jordan's weak economic and financial conditions in the 1980s were further aggravated by the disruptions associated with the 1990 Gulf War. However, real GDP rebounded by about 14 percent in 1992 on the strength of sustained activity in the construction, manufacturing, transportation and communications, and agricultural sectors. Construction-related activities were buoyant in response to increased demand for housing associated with the return of 300,000 Jordanians from neighboring countries in the aftermath of the 1990 regional crisis. Unemployment, which rose to a peak of about 20 percent in the aftermath of the regional crisis, declined to 16 percent in 1994 as workers were absorbed in fast growing labor-intensive sectors such as construction and tourism.

\section{Jordan in the aftermath of the 2003 invasion of Iraq}

- Jordan saw a strong economic recovery from the disruptions caused by the war in Iraq in the last quarter of 2003. Despite the disruption of exports to Iraq and the negative effects of the conflict on tourism and transportation, real GDP grew by 4 percent in 2003. Recovery was supported by a strong rebound in export growth, particularly from exports to the United States from the Qualified Industrial Zones. A fiscal stimulus funded through grants also contributed to the recovery in domestic demand. The fiscal deficit in 2003 was almost in balance, as spending overruns in the areas of defense and security and accelerated capital spending were offset by higher foreign grants associated with the Iraqi conflict. The external current account registered a large surplus in 2003, reflecting a surge in grant receipts and the underlying strength of the balance of payments. Refugees in Jordan strained the Jordanian water sector and increased demand for fuel, leading to increased prices. In addition, refugees have put pressures on health, transport, sanitation and security services..$^{13}$

\section{Syria in the aftermath of the 2003 invasion of Iraq}

- $\quad$ Compared to Jordan, Syria did not receive foreign grants, and it hosted a larger number of Iraqi refugees and who were more disadvantaged economically compared to Iraqis who went to Jordan. The large number of refugees had a significant negative effect on Syria, particularly on the infrastructure, inflation, property prices and rentals, as well as services, including education, health, and water, leading to a higher fiscal cost. ${ }^{14}$ All this exacerbated the macroeconomic situation in Syria in 2003 in the immediate aftermath of the war in Iraq. Real GDP contracted by about 2 percent in

\footnotetext{
${ }^{13}$ Harper (2008).

${ }^{14}$ See Al-Miqdad (2008).
} 
2003, from a growth of about 6 percent in 2002, due in part to the negative impact of the conflict in Iraq on exports and investment. CPI inflation rose to close to 6 percent mainly due to the euro appreciation, along with increases in administered prices, shortages of agricultural goods during the war in Iraq, and increasingly expansionary fiscal policy. The external current account posted a large deficit of about 8 percent of GDP in 2003 because of the large drop in exports, reflecting the disruption in trade with Iraq.

\section{Conclusions: What Can We Learn from the Past?}

Despite some broad commonalities, each war analyzed here has been unique, in terms of its impact on conflict and neighboring countries. The same applies to ongoing conflicts, making it difficult to quantify their economic impact and predict what their economy and recovery process would look like in their aftermath. However, the analysis presented here could help provide some insights into these questions.

Conflicts are expected generally to lead to a sharp contraction in output, a spike in inflation, large fiscal and current account deficits, a drop in foreign reserves, and pressures on the exchange rate - if the country does not have enough reserves to support its exchange rateand the conflict is long lasting. Depending on the financing of the fiscal deficit, inflation could spiral or total debt could increase sharply, as was the case in Lebanon. At the same time, the financial system is expected to weaken significantly. A longer lasting conflict would have a more negative economic impact on the economy and the more prolonged the recovery period would be.

The extent and the speed of recovery in conflict countries depended on its economic structure. Aggregate output recovered more quickly in oil-rich countries (Kuwait and Iraq). In Lebanon, aggregate supply took longer to catch up with growing aggregate demand. At the same time, the continuing excess demand reflected large fiscal and current account deficits. In Iraq and Kuwait, oil production represented a significant part of aggregate supply; recovery was faster because oilfields were reactivated relatively quickly; and with most oil production exported, they achieved current account surpluses in a relatively short period and recovered foreign reserves.

Based on the conflicts reviewed here, a country recovering from war could require: (i) large amounts of external assistance, particularly, for the reconstruction of damaged or destroyed physical, industrial, and socio-economic infrastructure; (ii) a post-war policy and institutional set up conducive to a more dynamic economic development model going forward when those are not in place; (iii) insertion in regional and global trade and foreign direct investment flows, (iv) restructuring of the financial sector, and (v) stable security and political conditions. 
Spillovers from conflict countries to their neighbors can take place through multiple channels, operating through: (i) flows associated with regional and global integration, including trade, tourism, transportation, and foreign investment; (ii) price effects at the micro level, particularly in real estate markets; (iii) migration of labor and capital; (iv) fiscal pressures from increased social services, such as education and health, and higher military and security spending; and (v) heightened regional uncertainty. The impact and the recovery process in neighboring countries would depend on their starting economic conditions, number and economic status of the refugees they host, how strong their trade, tourism and transportation links are with the country in war, and external assistance.

Finally, further research could include enlarging the sample of countries within and beyond the MENA region to allow economies to be grouped according to more disaggregated characteristic. While extending the sample could be quite resource and time intensive given the narrative approach and the need to construct a comprehensive dataset from different sources, this would help draw more general conclusions and check for robustness of the results. In addition, further research could involve assessing the impact of war on socio-economic indicators. 


\section{Appendix: Impact of Wars on Selected Countries ${ }^{1}$}

\section{A. Lebanese Civil War (April 13, 1975-October 13, 1990) ${ }^{2}$}

Background: In the ten years prior to 1975, the Lebanese economy was one of the most dynamic in the Middle East region. It was characterized by low inflation, high rates of economic growth, large balance of payments surpluses, small fiscal deficits, and a floating, stable, and fully convertible domestic currency. Regulations impinging on the functioning of markets for goods and services, labor, capital, and trade were limited, and tax burdens were light in comparison with other countries at a similar stage of development. Furthermore, Lebanon had an important role as the key economic intermediary between the developed economies of Europe and the developing economies of the Middle East. Because of this combination of a stable macroeconomic environment, liberal economics, and its role as regional intermediary, Lebanon enjoyed a strong comparative advantage in the services sector of its economy, particularly in banking and finance, tourism, insurance, and trade-related services.

Impact of the war on the economy: Lebanon's civil war, which started in 1975 and spanned 15 years, exacted a heavy toll in human and material terms and caused fundamental changes in the economy. The economy suffered from the destruction of infrastructure and industrial facilities, while the reluctance to invest resulted in the obsolescence of remaining production capacity. Moreover, the flow of goods and factors of production in Lebanon was disrupted as a result of the fragmentation of the country. There was mass emigration, with an accompanying loss in professional and entrepreneurial skills. The emigration of workers was accompanied by a flight of capital, and Lebanon's access to flows of foreign capital was much reduced. Meanwhile, Lebanon's public finances deteriorated significantly because of the lack of central government authority in the country and the consequent inability of the authorities to collect revenues while continuing to provide a minimum of public services. Large fiscal deficits were financed primarily through the banking system. The consequent rapid growth in liquidity compared with economic activity, and the erosion of private sector confidence, led to continuous pressures on the Lebanese pound in the exchange market, heightened inflationary pressures, and resulted in high levels of currency substitution. Furthermore, during the war the banking system was weakened considerably and Lebanon's role as a regional intermediary was greatly reduced. Nevertheless, Lebanon continued to maintain an exchange and trade system that was almost entirely free of restrictions on payments and transfers for current and capital transactions.

\footnotetext{
${ }^{1}$ Information for this appendix is extracted from Eken and others (1995), Chalk and others (1997), Eken and Helbling (1999), and from diverse staff reports, including IMF (2003b, 2004, and 2005).

${ }^{2}$ There were other incidents of conflicts or unrest in Lebanon that are not the scope of this study.
} 
Post-conflict recovery: The basis for a peaceful settlement to the civil war was provided by the 1989 Taif Accord for National Reconciliation. Following the accord, government authority was gradually restored, and hostilities came to an end in 1990. Confidence was restored in the last quarter of 1992 following the completion of parliamentary elections, the first in twenty years, and the installation of the new government.

The government took the lead in reconstruction by formulating first the National Emergency Reconstruction Program and subsequently the Horizon 2000 Program. The strategy, despite a difficult environment characterized by episodes of domestic political uncertainty, a fluid regional context, and limited external assistance for the reconstruction program, has been successful in several respects. Real GDP recovered gradually reaching its pre-war level in 2010 while real GDP per capita still remains well below its pre-war level (Appendix Figure 1). To stabilize expectations and achieve rapid disinflation, an exchange-rate-based nominal anchor policy was adopted starting at the end of 1992. The exchange-rate based nominal anchor policy was implemented by means of a supportive interest rate policy. High interest rates helped attract large capital inflows, which together with foreign investment into the real estate sector and financing for the reconstruction program, more than financed the large external current account deficits and led to a sharp increase in foreign exchange reserves. The decline in inflation, the stable exchange rate, and the buildup of reserves accompanied by the authorities' increased credibility in financial markets raised the demand for local currency. As a result, dollarization declined but remains well above its pre-war level.

A number of banks (mostly those severely affected by the war) closed or merged with existing ones, notably during 1990-93 and 1997-98. A law adopted in 1993 and expired in 1998 encouraged consolidation in the banking system, mainly through providing limited concessional loans from the central bank for the part of the acquisition cost that is related to the goodwill value.

However, the acceleration in the growth of capital expenditure, together with large and expanding current expenditure and the slow recovery of the revenue-generation capacity, led to sizable fiscal imbalances. While the deficit fell from 16 percent of GDP in 1991 to 8 percent in 1993, it rose and remained high thereafter. The deficits were financed mostly through the issuance of government papers denominated in Lebanese pounds and held primarily by the domestic banking system. Consequently, public debt increased rapidly. Moreover, the lack of adequate infrastructure, a weak institutional framework, and shortages of human capital continued to constrain overall economic recovery.

Spillovers from the Lebanese civil war into neighboring countries are considered to be limited as many Lebanese migrated to Gulf and Western countries. 


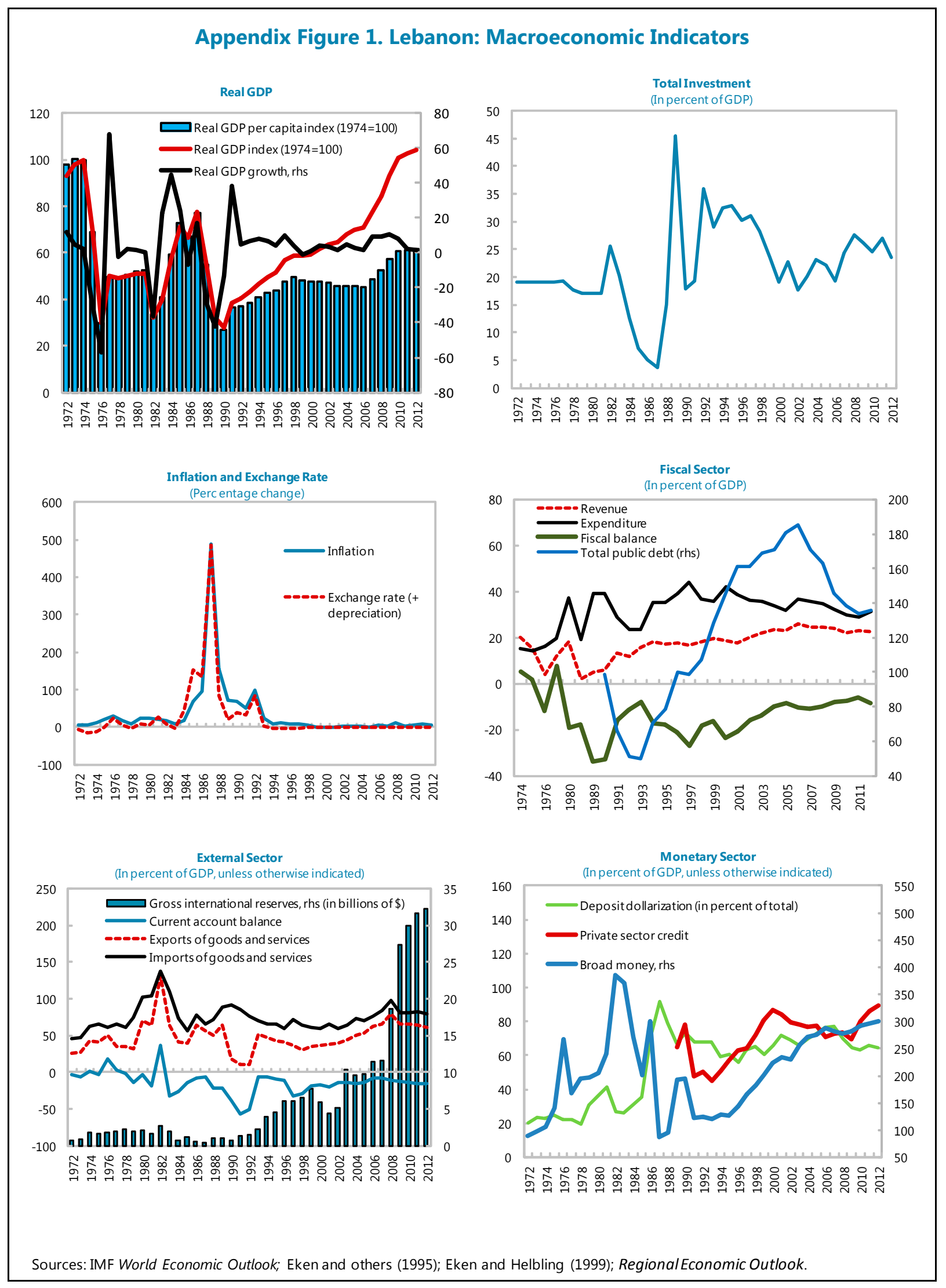




\section{B. Gulf War-Kuwait's Invasion by Iraq (August 2, 1990-February 28, 1991)}

Background: Prior to the Iraqi invasion, Kuwait had achieved considerable economic progress made possible by income from its substantial oil resources. Economic growth during the second half of the 1980s averaged 5.5 percent per year and prices increased by an average of 1.5 percent per year. While the economy remained dependent on the oil sectorrepresenting about 60 percent of GDP — other sectors, dominated by services and construction, gained in importance in domestic output throughout the 1980s. The role of the private sector, nevertheless, remained relatively modest. In early 1990, expatriate population accounted for about 70 percent of the total population of 2.1 million and 85 percent of the total labor force. Revenues from oil exports and investment earnings from accumulated official foreign assets contributed to large overall budget and current account surpluses. Kuwait had a liberal exchange and trade system. The Kuwaiti dinar was pegged to a currency basket from March 18, 1975-end-2002. Through most of the 1980s, the operations of the banking system remained constrained by the lingering effects of the stock market crash in 1982, which left banks with a large volume of nonperforming loans.

Impact of the war on the economy: Iraqi invasion inflicted widespread physical damage and resulted in large budgetary and balance of payments deficits, disrupted the domestic financial market, halted foreign trade, and paralyzed the labor market. Over 60 percent of the existing oil wells were set on fire. In addition to shutting down production, this constituted a major environmental hazard for water sources, the air, and marine life. The oil sector suffered further on account of damage to drilling rigs, oil-gathering centers, refineries, and oil-loading and shipping facilities. The physical disruption spread well beyond the oil sector. Communication systems were dismantled and damaged. Private and public buildings were looted, and records and statistical systems lost. All electricity-generating plants were damaged. Production of goods and services came to a virtual standstill during the Iraqi occupation.

The financial system was adversely affected as a result of the invasion. Financial contracts were severely disrupted, with assets serving as collateral destroyed. Some banking system's assets were looted, including the Central Bank of Kuwait's gold holdings and unissued currency. The value of real estate and financial assets plummeted. Finally, while the damage to the financial databases was contained by transferring the information abroad, there were some disruptions to records.

The Iraqi invasion and subsequent occupation led to a large-scale exodus of both Kuwaitis and expatriates. The sharp contraction of Kuwait's population by end-1991 had both supply and demand side factors. On the supply side, labor markets were disrupted by the absence of workers and the unavailability of certain skills. The resulting capacity constraints on the supply side were accompanied by a reduction in aggregate demand occasioned by lower consumption as a result of the fall in population. 
Post-conflict recovery: The comprehensive economic recovery and reconstruction program initiated in March 1991 following Kuwait's liberation from Iraqi occupation was largely complete by mid-1994. Real GDP per capita was well above its pre-invasion level by end-1993 (Appendix Figure 2). Oil sector infrastructure was quickly restored; the financial system rapidly resumed operations; and the restoration of economic and social infrastructure and services was virtually complete by end-1992. The steep domestic price increases that had occurred during the occupation were reversed by late 1991 following the opening of the economy to imports, and inflation after 1992 was small. The current account resumed its traditional surplus position in 1993.

Private sector confidence was subdued in the post-war period due to regional security, a large population reduction with adverse consequences for domestic demand, capacity utilization, as well as labor and skill availabilities, and uncertainty regarding the government's debt settlement program (see below). In this environment, the authorities took some steps to support private activity, including the restoration of the bank balances of nationals to pre-war levels and the cancellation of their consumer debt outstanding as banks reopened.

Budget developments over 1990/91-1991/92 were characterized by large revenue shortfalls, exceptional expenditure and deficit levels, and substantial draw-downs of government external reserves - all owing essentially to war-related factors. In 1990/91, oil exports collapsed and other revenue collections ceased during the war, while import duties and most fees and charges were waived following liberation. ${ }^{3}$ Expenditure rose significantly due largely to substantial transfers abroad representing payments for Desert Shield/Desert Storm as well as to Kuwaitis temporarily living abroad. ${ }^{4}$

The debt settlement program was approved in May 1992. It entailed the buy-out of government bonds of the "problem" loans extended to Kuwaiti nationals by domestic banks and investment companies. The buy-out addressed nonperforming credits (outstanding as of August 1990) related to the war and the 1982 stock market crisis, but in implementing the program, the authorities decided to classify all loans to nationals as nonperforming since virtually no service payments had been made subsequent to liberation given the uncertainty surrounding the final terms of the program. This virtually meant that the government assumed the burden of all bad debts by Kuwaiti nationals, thus replacing the private sector indebtedness by a large, public sector debt obligation. With the buy-out, commercial banks

\footnotetext{
${ }^{3}$ Government reserves are held in the Reserve Fund for Future Generations (RFFG) managed by the Kuwait Investment Authority and, therefore, are not recorded in gross international reserves.

${ }^{4}$ The debt Kuwait incurred to coalition allies to finance Desert Storm and continuing military expenditures were among the largest post-war spending the government had (Library of Congress, 1993).
} 
achieved strong capital adequacy positions on a Basle standard given the high proportion of government bonds in their portfolios.

\section{Spillovers}

\section{Impact on Jordan}

Following a prolonged period of deteriorating economic and financial conditions resulting from macroeconomic imbalances and structural distortions in the 1980s - which were further accentuated by the disruptions associated with the 1990 regional crisis - the Jordanian authorities adopted a medium-term adjustment program covering the period 1992-2002. After several years of decline or virtual stagnation, real GDP rebounded by about 14 percent in 1992 on the strength of sustained activity in the construction, manufacturing, transportation and communications and agricultural sectors (Appendix Figure 3). Construction-related activities were buoyant in response to increased demand for housing associated with the return of 300,000 Jordanians from neighboring countries in the aftermath of the 1990 regional crisis. Agricultural output rebounded as a result of good weather conditions. Investment also recovered in 1992, as was reflected in part by a sharp increase in the import of transportation equipment and machinery, and increased investments in manufacturing industries. Favorable import prices and an excellent agricultural harvest, coupled with prudent demand management stance and relative stability of the Jordan dinar, have contributed to a sharp deceleration of inflation to 4 percent in 1992. ${ }^{5}$ The rate of unemployment, which rose to a peak of about 20 percent in the aftermath of the regional crisis, declined to 16 percent in 1994 as workers were absorbed in the fast growing labor-intensive sectors such as construction and tourism.

\footnotetext{
${ }^{5}$ Since 1975 , the Jordan dinar was pegged officially to the SDR, but in practice it had been pegged to the dollar since late 1995. The dinar came under increasing pressure in 1988, and it was allowed to float in October 1988. In late May 1989, the dinar was pegged to the SDR. Following the start of the regional crisis, a parallel market rate emerged, which in November 1990 was nearly 10 percent more depreciated than the official rate. The parallel rate disappeared shortly following the end of the crisis.
} 


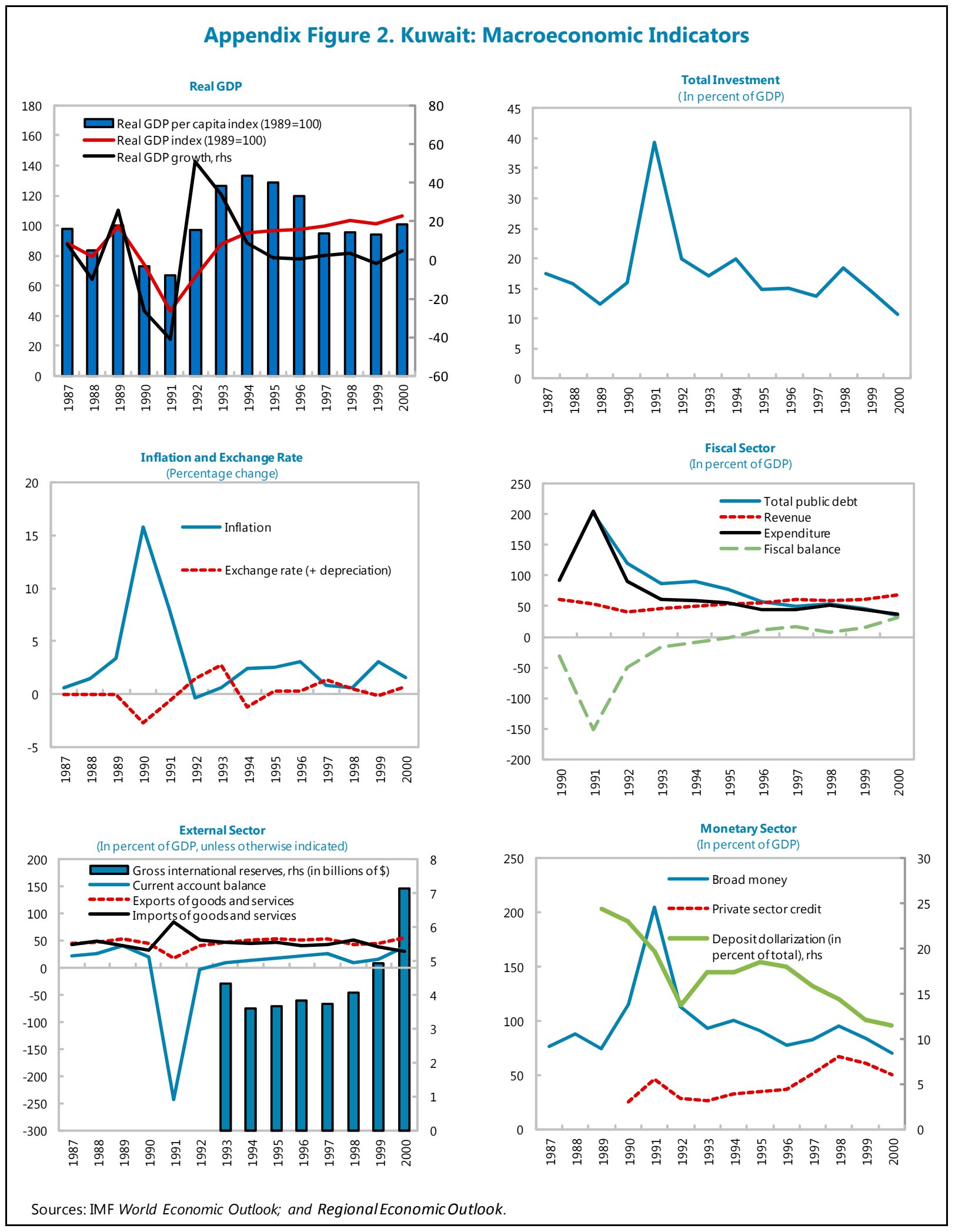




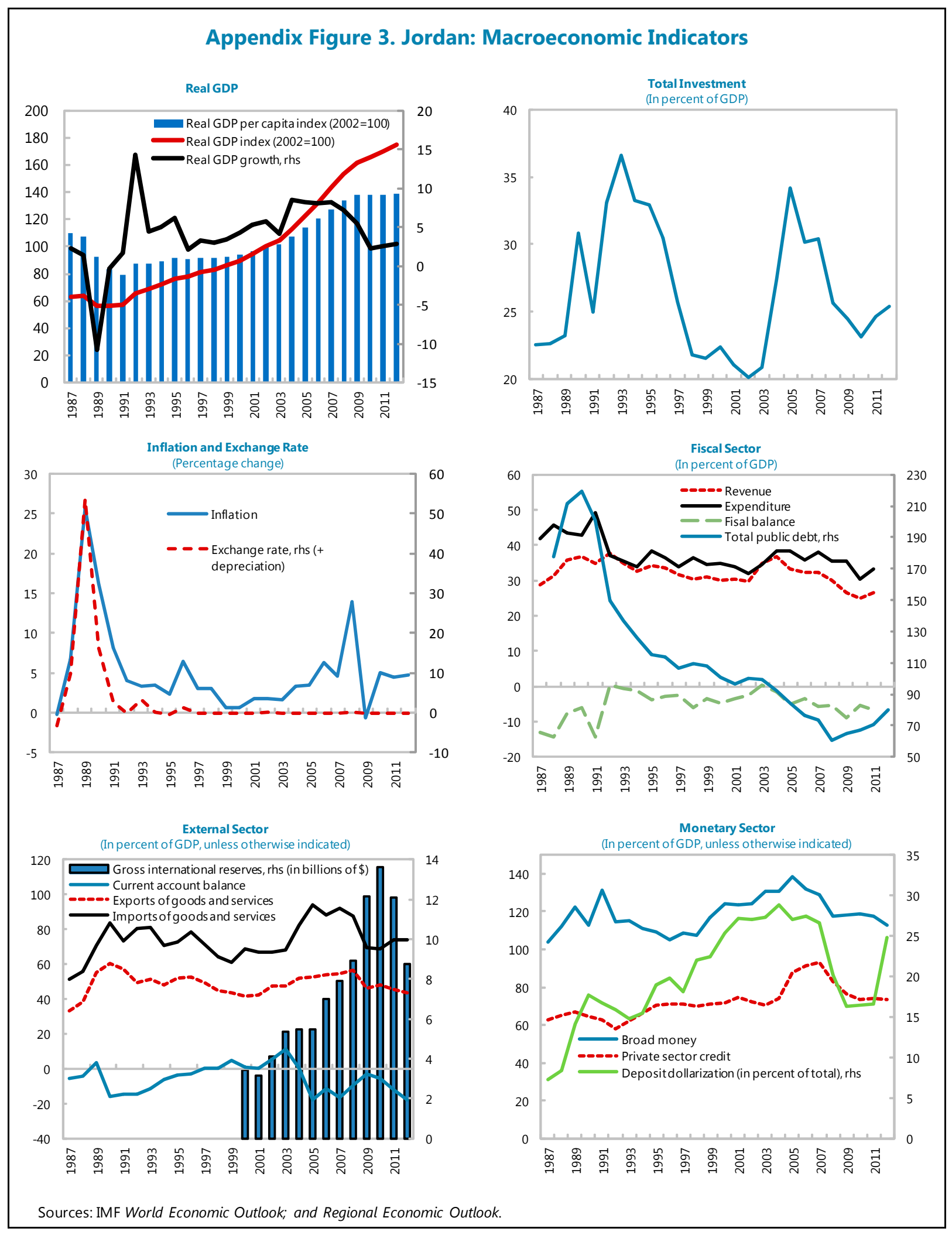




\section{2003 Invasion of Iraq (March 19-May 1, 2003)}

Background: Iraq is now estimated to have the world's second-largest oil reserves, with reserves of 143 billion barrels. By the 1970s, Iraq's oil resources had enabled the country to reach middle-income status, with a modern infrastructure, and good education and healthcare systems. The country suffered through three devastating wars, a long period of economic and financial mismanagement, and international sanctions imposed during the 1990s. These events severely damaged political and economic institutions and undid earlier economic and social gains. Iraq's real GDP per capita was estimated at about only $\$ 820$ in 2002, and the country suffered from a crippling debt burden. ${ }^{6}$

Impact of the war on the economy: Real GDP plummeted by about 35 percent in 2003, reflecting a contraction in oil production and a severe retrenchment in non-oil economic activity, which lasted for several months beyond the end of the major conflict in 2003 (Appendix Figure 4). Unemployment was estimated at about 28 percent in 2003. As a result of supply disruptions caused by the war, inflation increased to 34 percent during 2003 from 19 percent in 2002 . No central bank balance sheet was available at the time but at the beginning of the 2003 conflict, close to $\$ 1$ billion in foreign currency was taken out of the Central Bank of Iraq (CBI) vaults, but most of this was subsequently recovered and used to finance government operations. Gross international reserves of the CBI were reported to be about $\$ 1.1$ billion by end-2003. The looting of the main central bank building, combined with the destruction of several commercial bank branches exacerbated the shortage of bank notes in the immediate aftermath of the conflict. Moreover, a CBI printing press used for the production of ID 10,000 notes was stolen during the 2003 conflict, leading to a situation where these notes were traded at a discount of 20-30 percent because of the fear of counterfeiting. Since the CBI had not become fully operational, monetary policy was passive during the conflict. However, the lack of banknotes led to tight monetary conditions. This may have explained the exchange rate appreciation despite economic and political uncertainties. The 2003 conflict made it difficult to evaluate fiscal policy for the year as a whole. The quality of Iraq's statistical base was limited after years of institutional isolation, and was substantially weakened as a result of the conflict and the looting of offices in its aftermath. In 2003, government spending was essentially limited to wage payments to civil servants and employees of state-owned enterprises, which were paid since May 2003, and toward guaranteeing the distribution of basic goods through the commodity-based safety net.

Post-conflict recovery: Fund engagement with Iraq over almost a decade has been instrumental to maintaining macroeconomic stability and building institutions. The CBI followed a policy of exchange rate stability, which has translated in a de facto peg of the

\footnotetext{
${ }^{6}$ Debt numbers for Iraq were unavailable prior or during the war. It was, however, estimated that total public debt amounted to about 335 percent of GDP in 2004.
} 
exchange rate since early $2004 .^{7}$ The Fund has been closely working with the Iraqi authorities in the context of post-conflict assistance and Stand-By Arrangements since 2004. The authorities were able to limit fiscal spending, contain inflation, and successfully restructure Iraq's external debt. They also reformed the CBI and implemented new laws and regulations in fiscal and financial sectors. A large number of bilateral donors and multilateral agencies have participated in the reconstruction of Iraq. The Fund has provided significant technical assistance in all economic sectors. However, the economy remains extremely vulnerable to the country's ongoing security problems, which impede investment and private economic activity. The financial system remains seriously underdeveloped and is dominated by two state-owned commercial banks.

\section{Spillovers}

\section{Impact on Jordan}

Jordan saw a strong economic recovery from the disruptions caused by the war in Iraq in the last quarter of 2003. Despite the disruption of exports to Iraq and the negative effects of the conflict on tourism and transportation, real GDP grew by 4 percent in 2003 (Appendix Figure 3). Recovery was supported by a strong rebound in export growth, particularly from exports to the United States from the Qualified Industrial Zones. A fiscal stimulus through higher public spending funded through grants also contributed to the recovery in domestic demand. Inflation remained subdued. The Amman Stock Exchange reached record highs in February 2004 on expectations of a positive outlook for the medium term.

The fiscal deficit in 2003 was almost in balance, as spending overruns in the areas of defense and security and accelerated capital spending were offset by higher foreign grants associated with the Iraqi conflict. Higher tax revenues partly offset nontax revenue shortfalls. In particular, general sales tax collections increased strongly, boosted by high import growth and improved revenue administration. Military spending and current transfers registered sizable overruns, reflecting the difficult geopolitical situation in the region and the need to compensate economic sectors adversely affected by the war in Iraq. Capital spending accelerated to stimulate slack in the domestic demand in the aftermath of the war in Iraq.

The external current account registered a large surplus in 2003, reflecting a sharp increase in grant receipts and the underlying strength of the balance of payments. Exports grew by an annual rate of 11 percent, despite the disruption of exports to Iraq during the war.

\footnotetext{
${ }^{7}$ However, from November 2006 until end-2008, the CBI allowed the exchange rate to gradually appreciate. As a result, the exchange rate arrangement of Iraq was reclassified to the category of crawling peg effective November 1, 2006. Since the start of 2009, the CBI returned to its earlier policy of maintaining a stable dinar. Consequently, the exchange rate arrangement of Iraq was reclassified effective January 1, 2009 as a stabilized arrangement.
} 
Nontraditional exports fared particularly well, including textiles and apparel mainly to the U.S. market. Re-export activity to Iraq rebounded strongly in the second half of the year. The strong export performance was only partly offset by faster-than-anticipated import growth (13 percent), reflecting a pickup in domestic demand and higher oil imports. Tourism receipts recovered in the second half due to an increase of regional visitors and official and business travels related to the situation in Iraq, while remittances grew by 2 percent. With grant receipts of almost $\$ 1.4$ billion (about 13.5 percent of GDP), the external current account surplus for 2003 was 11.5 percent of GDP. Meanwhile, public sector loan disbursements were lower than programmed and net private capital flows registered a strong surplus. As a result, gross official reserves increased by about $\$ 1$ billion to reach $\$ 5.4$ billion in 2003.

Monetary aggregates expanded at a strong pace, reflecting the strength of the balance of payments. Broad money grew by an annual rate of about 12.5 percent in 2003 , supported by a surge in net foreign asset (NFA) inflows, a large part of which was also channeled into Jordanian dinar deposits. Private sector credit growth continued to be low, as banks remained cautious and demand for credit was met mainly through a utilization of deposits. The large increase in NFAs was only partly sterilized through an increase in bank deposits at the Central Bank of Jordan overnight window facility and bank holdings of CDs. The dollarization ratio increased by 1.5 percentage points to about 29 percent of deposits in 2004 , mainly because of Iraqi citizens' demand for dollar deposits in Jordan, but declined again in 2005.

\section{Impact on Syria}

The macroeconomic situation weakened in 2003 in the aftermath of the war in Iraq. Real GDP contracted by about 2 percent in 2003, from a growth of about 6 percent in 2002, due in part to the negative impact of the conflict in Iraq on exports and investment (Appendix Figure 5). CPI inflation rose to close to 6 percent mainly due to the euro appreciation, along with increases in administered prices, shortages of agricultural goods during the war in Iraq, and increasingly expansionary fiscal policy. Due to a sharp increase in the wage bill and development expenditure, along with a drop in oil revenue, the fiscal position deteriorated in 2002 and 2003, with the deficit reaching 2 percent and 2.7 percent of GDP, respectively, following a record surplus equivalent to 2.3 percent of GDP in 2001. After three years of rapid increase driven by a large accumulation of net foreign assets, broad money growth decelerated during the first half of 2003 on account of lower export proceeds and private capital inflows. Monetary policy was relaxed by reductions in administered interest rates in June and December 2003. The external current account posted a large deficit of about 8 percent of GDP in 2003 due to large drops in exports, reflecting the disruption in trade with Iraq. The exchange rate remained broadly stable overall in 2002-03 vis-à-vis the dollar, despite temporary spikes due to regional developments. 


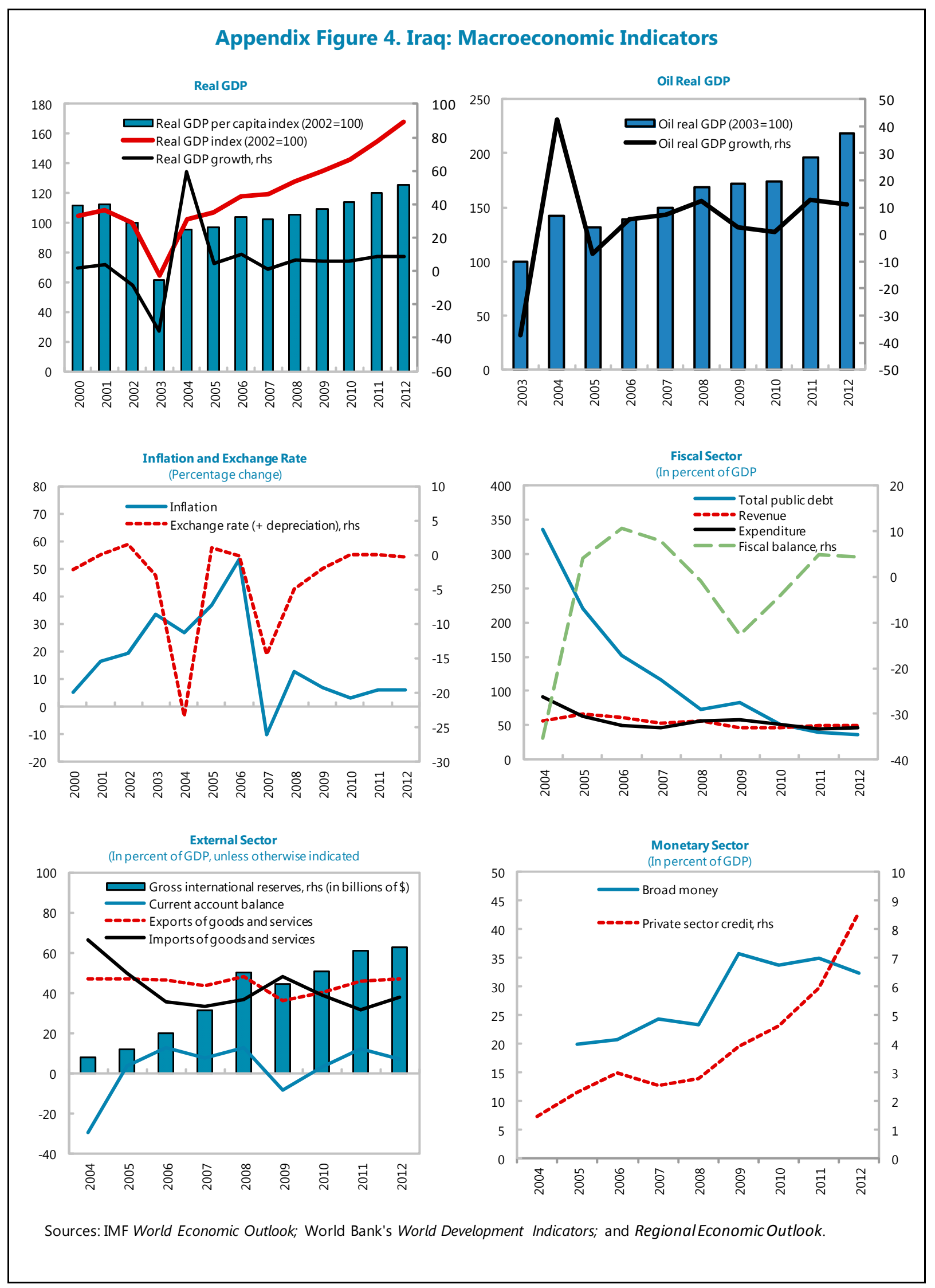




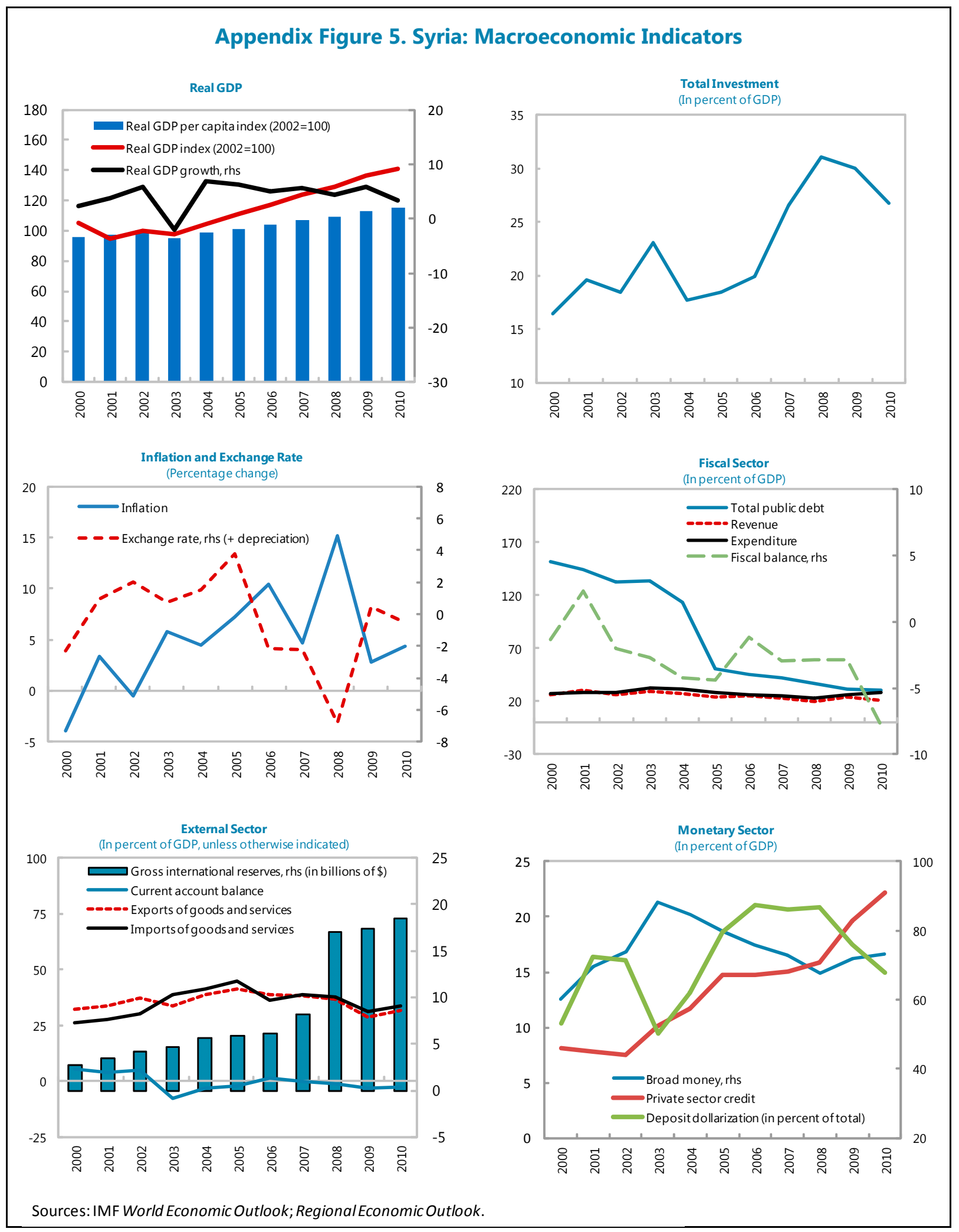

CInternational Monetary Fund. Not for Redistribution 


\section{References}

Addison, Tony, Abdur R. Chowdhury, and S. Mansoob Murshed, 2002, "By How Much Does Conflict Reduce Financial Development?" WIDER Discussion Paper No. 2002/48 (Helsinki: World Institute for Development Economic Research, United Nations University).

Ades, Alberto, and Hak B. Chua, 1997, “Thy Neighbor's Curse: Regional Instability and Economic Growth,” Journal of Economic Growth, Vol. 2 (September), pp. 279-304.

Al-Miqdad, Faisal, 2008, "Iraqi Refugees in Syria,” FMR Iraq Special Issue, No. 19.

Bennett, D. Scott and Alan C. Stam III, 1996, "The Duration of Interstate Wars, 1816-1985," American Political Science Review, Vol. 90, No. 2, pp. 239-57.

Caselli, Francesco, 2008, "Growth Accounting," The New Palgrave Dictionary of Economics, London: Palgrave MacMillan: Second Edition, edited by Steven N. Durlauf and Lawrence E. Blume.

Chalk, and others, 1997, Kuwait: From Reconstruction to Accumulation for Future Generations, IMF Occasional Paper No. 150 (Washington: International Monetary Fund).

Collier, Paul, 1999, "On the Economic Consequences of Civil War," Oxford Economic Papers 51, pp. 168-83, Oxford University Press.

Collier, Paul and Anke Hoeffler, 1998, "On the Economic Causes of Civil War," Oxford Economic Paper, Vol. 50, No. 4, pp. 563-73.

Collier, Paul, Anke Hoeffler, and Mans Soderbom, 2004, "On the Duration of Civil War," Journal of Peace Research, Vol. 41, No. 3, 2004, pp. 253-73.

De Groot, Olaf J., 2010, The Spillover Effects of Conflict on Economic Growth in Neighboring Countries in Africa," Defence and Peace Economics, 2010, Vol 2, No. 2 (April), pp. 149-64.

Economic Intelligence Unit, EIU, 2003, Country Profile, London, United Kingdom.

Eken, Sena, and others, 1995, Economic Dislocation and Recovery in Lebanon, IMF Occasional Paper No. 120 (Washington: International Monetary Fund). 
Eken, Sena, and Thomas Helbling, 1999, Back to the Future: Postwar Reconstruction and Stabilization in Lebanon, IMF Occasional Paper No. 176 (Washington: International Monetary Fund).

Gupta, Sanjeev, and others, 2002, "Fiscal Consequences of Armed Conflict and Terrorism in Low- and Middle-Income Countries," IMF Working Paper 02/142 (Washington: International Monetary Fund).

Harper, Andrew, 2008, “Iraq's Refugees: Ignored and Unwanted," Volume 90, No. 869, pp. 169-90.

International Monetary Fund, 2003a, Jordan — Letter of Intent, Memorandum of Economic and Financial Policies, and Technical Memorandum of Understanding, June 19, 2003.

—, 2003b, Iraq, Macroeconomic Assessment, October 21, 2003.

— 2004, Iraq — Letter of Intent, Memorandum of Economic and Financial Policies, and Technical Memorandum of Understanding, September 24, 2004.

— 2005, IMF Executive Board Concludes 2005 Article IV Consultation, Post-Program Monitoring Discussions, and Ex Post Assessment with Jordan, Public Information Notice (PIN) No. 06/02, January 5, 2006.

Library of Congress, 1993, "Reconstruction After the Persian Gulf War," http://countrystudies.us/persian-gulf-states/33.htm.

Salti, Nisreen, "The Economic Cost of Political Instability," The Lebanese Center for Policy Studies, April 6, 2012.

Sdralevich and others, 2013, Iraq: 2013 Article IV Consultation, IMF Staff Country Report No. 13/217 (Washington: International Monetary Fund).

United Nations High Commissioner for Refugees, July 2009, Surviving in the city: A review of UNHCR's operation for Iraqi refugees in urban areas of Jordan, Lebanon and Syria, PDES/2009/03. 